Session 3460

\title{
Engineering Education in the Next Millennium in India
}

\author{
Prof. A. Janaki Rao \\ Emeritus Professor, Andhra University/Secretary, UNISPAR Working Group of India \\ 22-HIG, Lawsons Bay Colony, Visakhapatam, Pin 530017 (India) \\ e-mail : ajanaki_rao@hotmail.com
}

Introduction

Engineering Education in developing Countries (More so in India) is neither able to meet the varied and changing Industrial demands nor socially relevant and productive. The Industrial needs are many and varied. The local, national and global needs are rapidly changing. The Industry complains that Engineering Graduates are not readily employable, but need further Training. There is mismatch between the knowledge, curriculum and skills imparted by Technical Institutions and Industrial needs. Universities are not able to inspire the Industries to come to the academic platform and, make use of their expertise in structuring Engineering Education.

Little attention is being paid by universities for the ever growing and diverse social needs. The fruits of Technology are not reaching the downtrodden and under previlized in the society. Taking these points into consideration a model is developed for a more useful productive and socially relevant Engineering Education System.

1. India - some social indicators

India is a country with 25 states, 14 major languages and different Socio-economic and cultural backgrounds. Indian social structure is unique, blend of diverse religious, culture and racial groups. The uniqueness of Indian social structure lies in its unity in diversity.

Total Population

Area

Urban population

Rural population

Literacy

Female literacy

Population without access to health services

Population without access to safe drinking water

People without access to sanitation

Universities
97.8 millions

3287263 Sq. km

$27 \%$

$73 \%$

$52.11 \%$

$36 \%$

135.2 millions

171.3 millions

640 millions

226 


\section{Technical Education in India}

India has 700 Engineering Colleges admitting more than 0.15 million students annually. Their locations however do not follow any Geographical pattern $(68 \%$ of the colleges are located in the four States of Andhra Pradesh, Tamil Nadu, Karnataka and Maharashtra). There are 7 Institutes of Technologies (IITs). These are the Institutes of excellence and 17 Regional Engineering Colleges (REC) followed by University Engineering Colleges, Government engineering colleges and Self Financed Engineering Colleges.

Status of Engineering Education and Technical Institutions in India are shown in Annexure - 1 .

3. The present curriculum structure in India

Curriculum is not planned either to the Industrial demands or needs of society. The following subjects are covered.

$\begin{array}{llr}\text { Basic sciences } & : & 10.8 \% \\ \text { Engineering sciences } & : & 17.2 \% \\ \text { Technical Arts } & : & 20.1 \% \\ \text { Applied and Design Engineering } & : & 43.8 \% \\ \text { Miscellaneous subjects } & : & 8.1 \% \\ \text { Total } & : & 100.0 \%\end{array}$

4. The structure of engineering curriculum in USA

Most of the good Universities in USA design their curriculum keeping in mind Technological changes, Industrial demands and to social needs. The subjects covered are as follows.

$\begin{array}{llr}\text { Basic sciences } & : & 25.0 \% \\ \text { Engineering sciences } & : & 25.0 \% \\ \text { Technical Arts } & : & 2.8 \% \\ \text { Applied and Design Engineering } & : & 22.2 \% \\ \text { Humanities and Social Sciences } & : & 22.2 \% \\ \text { Thesis } & : & 2.8 \%\end{array}$

\section{Structure}

A comparison of the structures reveals and shows striking differences. The first difference is in the coverage of basic sciences. The percentage is lower in India. The second difference is the time spent in technical arts. In USA no time is allotted to Workshop, drawing and Computer Programming. The probable reason for this is that most students in USA who opt for engineering have done some Workshop practice and Computer Programming at the high school level. Drawing is not considered to be an essential subject any more presumably because of the availability of many software packages for drafting and drawing. The third difference is that in India considerable time is spent on Applied and Design Engineering subjects in which a fair amount of empirical information is included. This is not considered essential in USA. Instead they find it more profitable, to spend nearly $20 \%$ of the time in the teaching subjects in Humanities and Social Sciences. Excepting for some exposure to economics, these do not find a place in the Indian curriculum. 
Apart from the differences in structures, two important factors differentiating the U.S. curriculum from Indian curriculum are in the nature of the flexibility offered and the innovativeness inherent in project type laboratories. The flexibility enables to cater to the needs of different categories of students those who will base their professional careers as engineers on the Bachelor's degree with no further formal study; those who will proceed further for post graduate studies in engineering or an allied field, and those for whom the under-graduate programme provides a broad base for further professional study in fields like management.

The use of open-ended project type laboratories instead of set laboratory experiments greatly enhances the learning process.

\section{Flexibility of approach}

University Industry Partnership was (Industry Institute Interaction I.I.T.) discussed several times on various platforms, seminars, symposia, workshops and conferences, but the distance between institutions and industry could be reduced, if at all, only marginally. The main reason for this, is the rigidity in the educational system. The institutions are governed by the State Governments and academically by the universities and there is no mechanism to watch and ascertain the changing demands of man power required by the industry. Even to make a small change in syllabus, it takes more than a year to go through the process of Boards of Studies, Faculty and the Academic Councils of the University, introducing new courses is almost out of question. What is required is autonomous Institutions and institutions willing to run need based courses on requisition. There are enough of colleges some of which may be centres of excellence, but these run stereo-typed, Diploma, Graduate and Postgraduate Courses. New institutions must emerge who can cater to the changing demands of the industry. Industry has to pay for this Educational and training services.

\section{The Role of Employers}

For quite sometime employers in India have mostly recruited graduates of government funded universities. Now as there is more freedom allowed for private enterprises there is greater choice to industries in manpower selection. Industries can also take part in technical training.

The ultimate survival of any industry is its productivity for which technological excellence is a must. Good training and goal setting programmes have a far greater impact on productivity.

\section{Some suggestions for Improvement}

$\Rightarrow \quad$ There is a need for reducing the number of subjects taught in a semester to five or six, and the contact hours of instruction to a maximum 30 per week. The reduction in contact hours implies that the student is expected to do more work on his own in the form of self-study and assignment.

$\Rightarrow \quad$ More flexibility is to be provided in the form of elective subjects so that the curriculum caters to the local and regional needs. 
$\Rightarrow \quad$ Hands on experience should be conveyed through open-ended project type laboratories.

$\Rightarrow \quad$ The emphasis on some of the technical arts, particularly drawing and workshop practice, could be reduced.

$\Rightarrow \quad$ The coverage of basic sciences should be improved.

$\Rightarrow \quad$ The possibility of introducing some subjects in the Humanities and Social Sciences should be seriously examined. Subjects in Psychology, Sociology and Economics as applied to industry are of particular relevance in the Indian context. Subjects which covers Social needs, legal aspects in technology, patent laws, aspects of international trade and commerce, history of science and technology, etc. should be introduced.

The Model :-

Taking into accounts the above patterns and trends in Engineering Education, a model is developed to suit the social and industrial needs (Annexures 2,3,4). A systematic appraisal of academic programs and socio-economic and Industrial needs should be under taken by comprehension data collection for general and specific needs and with constant upgradetion and projections. This work can be entrusted to students as part of their project work. User and beneficiary participation (by way of workshops, short term courses, seminars, conference conducted by University and Industry) will bring scientific approach for curriculum design, training and retraining for the work force. Keeping the Core and Basic science component as common, Electives can be offered to meet the local and regional needs. This also provides necessary flexibility and to change the Electives when the needs are fulfilled. The Model presented represents the various (Interactions and participation) between society, Industry and University for developing a socially relevant and Industrial useful Technical education.

Traditionally Indian Society is slow in adoption and resists changes and so continues feedback and exchange of views are necessary.

9. Conclusion

* The curriculum in Engineering Education must be flexible to suit the contemporary needs of Industry and Society and scope for Vertical and Horizontal mobility.

* Minimum response time for changing the curriculum based on Industrial demands and needs of Society.

Acknowledgments

The author thanks Prof. V.C. Kulandaiswamy, Prof. R. Natrajan, Prof. S.P. Sukhamte, Prof. Ramanujam and Prof. N.V. Ratnalikar for making use of some of their material and ideas in preparing the paper. 
ANNEXURE 1
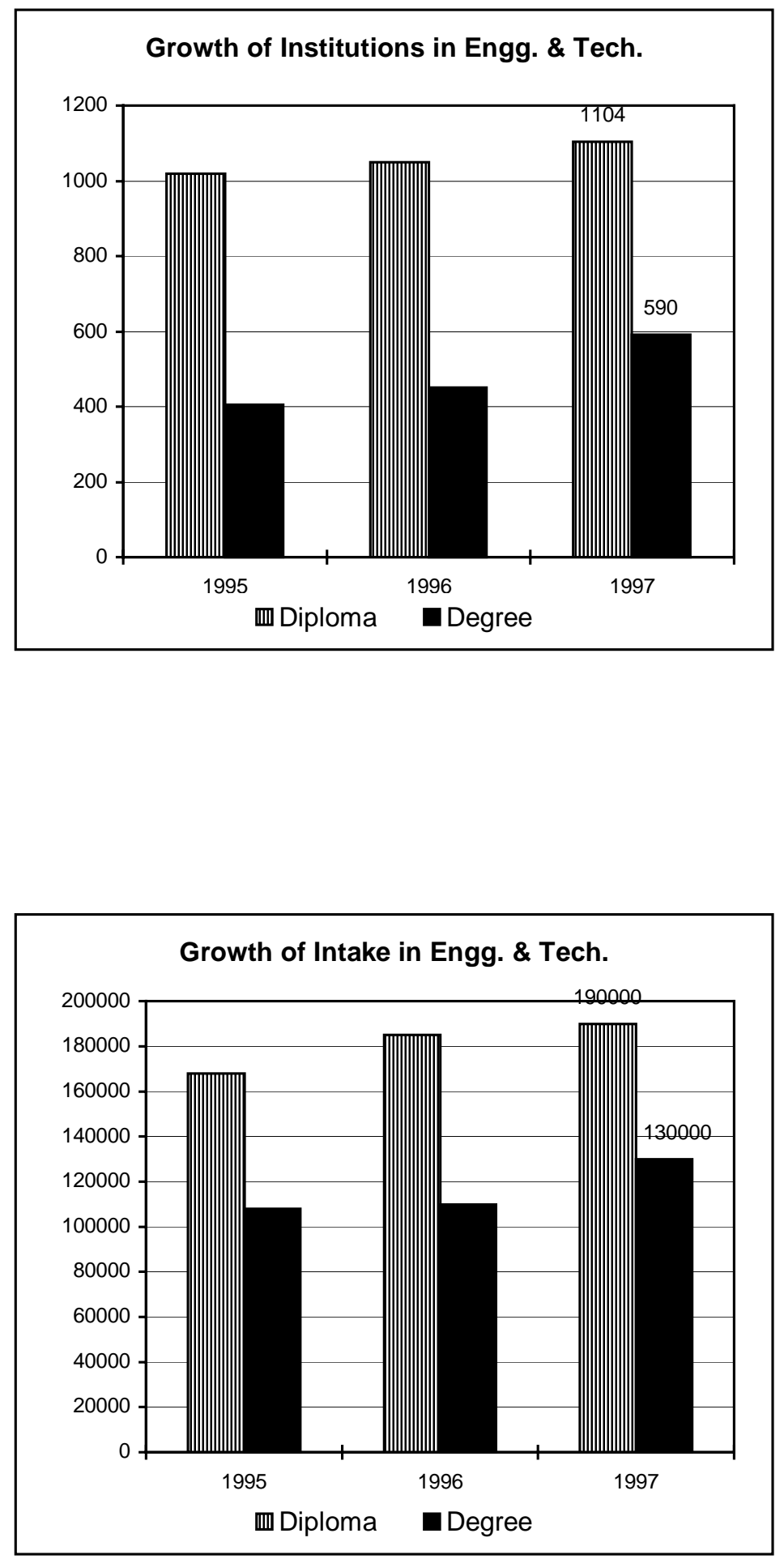
Actual and Estimated Growth of Engineering Institutions at Degree Level

\begin{tabular}{|r|r|r|r|}
\hline Year & $\begin{array}{c}\text { No. of } \\
\text { Institutions }\end{array}$ & \multicolumn{1}{|c|}{ Intake } \\
Capacity & $\begin{array}{c}\text { Out turn } \\
\text { of } \\
\text { graduates }\end{array}$ \\
\hline 1947 & 46 & 320 & 270 \\
\hline 1950 & 58 & 778 & 2021 \\
\hline 1970 & 163 & 18207 & 82232 \\
\hline 1990 & 339 & 87221 & 414654 \\
\hline 1997 & 600 & 110000 & 61680 \\
\hline 2000 & 580 & 128000 & 715524 \\
\hline 2005 & 740 & 148000 & 91377 \\
\hline 2010 & 944 & 188000 & 110000 \\
\hline 2015 & 1205 & 241000 & 150000 \\
\hline 2020 & 1600 & 310000 & 190000 \\
\hline 2025 & 2000 & 400000 & 250000 \\
\hline
\end{tabular}

Out turn of Engineering graduates in various disciplines in the years 1991-1997

\begin{tabular}{|l|r|r|r|r|r|r|r|}
\hline Discipline & $\mathbf{1 9 9 1}$ & $\mathbf{1 9 9 2}$ & $\mathbf{1 9 9 3}$ & $\mathbf{1 9 9 4}$ & $\mathbf{1 9 9 5}$ & $\mathbf{1 9 9 6}$ & $\mathbf{1 9 9 7}$ \\
\hline Chemical & 1928 & 1796 & 1928 & 3213 & 3213 & 3213 & 3283 \\
\hline Civil & 8514 & 8147 & 8514 & 8127 & 8127 & 8163 & 8163 \\
\hline Computer & 7011 & 7304 & 7600 & 9106 & 9127 & 9227 & 9519 \\
\hline Electrical & 5399 & 3716 & 5399 & 7108 & 7108 & 7192 & 7430 \\
\hline Electronics & 6746 & 7322 & 11269 & 11405 & 11561 & 11893 & 11884 \\
\hline Instrument & 863 & 845 & 863 & 2388 & 2478 & 2567 & 2733 \\
\hline Production & 1112 & 1030 & 1122 & 3522 & 3522 & 3544 & 3589 \\
\hline Mechanical & 9527 & 9538 & 9850 & 12415 & 12457 & 12605 & 12880 \\
\hline Mining & 348 & 536 & 536 & 402 & 402 & 402 & 403 \\
\hline Metallurgy & 497 & 469 & 497 & 489 & 489 & 489 & 489 \\
\hline Textile & 459 & 414 & 459 & 626 & 626 & 626 & 658 \\
\hline Misc. & 829 & 829 & 829 & 829 & 829 & 829 & 829 \\
\hline Total & 42963 & 41946 & 44909 & 59494 & 59853 & 60419 & 61860 \\
\hline
\end{tabular}


Out turn of Engineering graduates in various disciplines in the years 1998-2005

\begin{tabular}{|c|c|c|c|c|c|c|c|c|}
\hline Discipline & 1998 & 1999 & 2000 & 2001 & 2002 & 2003 & 2004 & 2005 \\
\hline Chemical & 3465 & 3808 & 3864 & 4285 & 4523 & 4762 & 5001 & 5240 \\
\hline Civil & 8163 & 8223 & 8223 & 8113 & 8091 & 8068 & 8046 & 8023 \\
\hline Computer & 10119 & 11094 & 11939 & 11716 & 12186 & 12656 & 13126 & 13596 \\
\hline Electrical & 7906 & 8704 & 8746 & 9492 & 9968 & 10445 & 10921 & 11398 \\
\hline Electronics & 14450 & 15560 & 15635 & 17161 & 18223 & 19286 & 20349 & 21411 \\
\hline Instrument & 3033 & 3078 & 3078 & 3777 & 4066 & 4354 & 4642 & 4930 \\
\hline Production & 3634 & 3754 & 3754 & 4713 & 5051 & 5388 & 5726 & 6063 \\
\hline Mechanical & 13512 & 14768 & 14553 & 15558 & 16177 & 16795 & 17414 & 18033 \\
\hline Mining & 402 & 420 & 420 & 399 & 394 & 389 & 384 & 379 \\
\hline Metallurgy & 489 & 489 & 489 & 490 & 490 & 490 & 490 & 490 \\
\hline Textile & 668 & 722 & 758 & 800 & 836 & 872 & 908 & 944 \\
\hline Misc. & 829 & 865 & 865 & 855 & 859 & 862 & 866 & 869 \\
\hline Total & 66670 & 71195 & 71524 & 77359 & 80863 & 84368 & 87873 & 91377 \\
\hline
\end{tabular}

Stock of Engineering graduates in various disciplines in the years 1990-1997

\begin{tabular}{|l|r|r|r|r|r|r|r|}
\hline Discipline & \multicolumn{1}{|c|}{$\mathbf{1 9 9 1}$} & $\mathbf{1 9 9 2}$ & $\mathbf{1 9 9 3}$ & $\mathbf{1 9 9 4}$ & \multicolumn{1}{|c|}{1995} & $\mathbf{1 9 9 6}$ & \multicolumn{1}{c|}{$\mathbf{1 9 9 7}$} \\
\hline Chemical & 33268 & 35064 & 36992 & 40205 & 43418 & 46631 & 49914 \\
\hline Civil & 128454 & 136601 & 145115 & 153242 & 161369 & 169532 & 177695 \\
\hline Computer & 16511 & 23815 & 31415 & 40521 & 49718 & 58945 & 68464 \\
\hline Electrical & 92429 & 96145 & 101544 & 108642 & 115760 & 122952 & 130382 \\
\hline Electronics & 48576 & 55898 & 63220 & 74489 & 85894 & 97455 & 109348 \\
\hline Instrument & 3543 & 4388 & 5251 & 7639 & 10117 & 12685 & 15418 \\
\hline Production & 5972 & 7002 & 8114 & 11636 & 15158 & 18702 & 22219 \\
\hline Mechanical & 140457 & 149995 & 159845 & 172260 & 184717 & 197322 & 210202 \\
\hline Mining & 4838 & 5374 & 5910 & 6312 & 6714 & 7116 & 7518 \\
\hline Metallurgy & 13617 & 14086 & 14583 & 15072 & 15561 & 16050 & 16539 \\
\hline Textile & 8389 & 8803 & 9262 & 9888 & 10514 & 11040 & 11790 \\
\hline Misc. & 829 & 1658 & 2487 & 3316 & 4145 & 4974 & 5803 \\
\hline Total & 496883 & 538829 & 538738 & 643232 & 703085 & 763504 & 825364 \\
\hline
\end{tabular}


Stock of Engineering graduates in various disciplines in the years 1998-2005

\begin{tabular}{|l|r|r|r|r|r|r|r|}
\hline Discipline & \multicolumn{1}{|c|}{$\mathbf{1 9 9 9}$} & \multicolumn{1}{c|}{$\mathbf{2 0 0 0}$} & \multicolumn{1}{c|}{$\mathbf{2 0 0 1}$} & \multicolumn{1}{c|}{$\mathbf{2 0 0 2}$} & \multicolumn{1}{c|}{$\mathbf{2 0 0 3}$} & $\mathbf{2 0 0 4}$ & \multicolumn{1}{|c|}{$\mathbf{2 0 0 5}$} \\
\hline Chemical & 57187 & 6100551 & 65336 & 69859 & 74621 & 79662 & 84862 \\
\hline Civil & 194081 & 202304 & 210417 & 218508 & 226576 & 234622 & 242646 \\
\hline Computer & 89677 & 100816 & 112532 & 124719 & 137375 & 150502 & 160498 \\
\hline Electrical & 146992 & 155738 & 165230 & 175198 & 185642 & 196563 & 207961 \\
\hline Electronics & 139358 & 154993 & 172154 & 190377 & 209663 & 230012 & 251423 \\
\hline Instrument & 21529 & 24607 & 28384 & 32450 & 36804 & 41445 & 46375 \\
\hline Production & 29679 & 33433 & 38146 & 43197 & 48585 & 54311 & 60374 \\
\hline Mechanical & 238192 & 252745 & 268303 & 283379 & 301275 & 318689 & 336721 \\
\hline Mining & 8340 & 8760 & 9159 & 9553 & 9942 & 10326 & 10705 \\
\hline Metallurgy & 17517 & 18006 & 18496 & 18985 & 19475 & 19965 & 20455 \\
\hline Textile & 13180 & 13938 & 14738 & 15573 & 16445 & 17353 & 18297 \\
\hline Misc. & 7497 & 8362 & 9217 & 10076 & 10939 & 11805 & 12674 \\
\hline Total & 963229 & 1034753 & 1112112 & 1192975 & 1277343 & 1365215 & 1456592 \\
\hline
\end{tabular}

Stock of Scientific \& Technical Persons in India 1950-1996 (No. in Lacks)

\begin{tabular}{|l|c|c|c|c|c|c|}
\hline & $\mathbf{1 9 5 0}$ & $\mathbf{1 9 6 0}$ & $\mathbf{1 9 7 0}$ & $\mathbf{1 9 8 0}$ & $\mathbf{1 9 9 0}$ & $\mathbf{1 9 9 6}$ \\
\hline $\begin{array}{l}\text { Engg. \& Technology (Degree and } \\
\text { Diploma) }\end{array}$ & 0.53 & 1.37 & 4.3 & 5.51 & 11.90 & 20.2 \\
\hline $\begin{array}{l}\text { Science, Natural Science, Medicine \& } \\
\text { Agriculture }\end{array}$ & 1.4 & 3.13 & 7.45 & 12.14 & 26.20 & 44.48 \\
\hline Total & 1.93 & 4.5 & 11.75 & 17.65 & 38.10 & 66.7 \\
\hline
\end{tabular}

Expected Stock of Scientific \& Technical Persons in India 2000-2025 (No. in Lacks)

\begin{tabular}{|l|c|c|c|c|c|c|}
\hline & $\mathbf{2 0 0 0}$ & $\mathbf{2 0 0 5}$ & $\mathbf{2 0 1 0}$ & $\mathbf{2 0 1 5}$ & $\mathbf{2 0 2 0}$ & $\mathbf{2 0 2 5}$ \\
\hline $\begin{array}{l}\text { Engg. \& Technology } \\
\text { (Degree and Diploma) }\end{array}$ & 26.91 & 37.52 & 50.43 & 65.25 & 86.5 & 109.4 \\
\hline $\begin{array}{l}\text { Science, Natural Science, } \\
\text { Medicine \& Agriculture }\end{array}$ & 59.2 & 82.54 & 117.64 & 150.1 & 198.95 & 262.7 \\
\hline Total & 86.11 & 120.06 & 168.07 & 215.35 & 285.45 & 372.1 \\
\hline
\end{tabular}


Expected Stock of Scientific \& Technical Persons per Thousand Population India in years 1991-2025

\begin{tabular}{|r|r|r|r|}
\hline Year & $\begin{array}{c}\text { Population } \\
\text { in Million }\end{array}$ & $\begin{array}{c}\text { S \& T } \\
\text { Personnel } \\
\text { in Million }\end{array}$ & $\begin{array}{c}\text { S \& T Personnel } \\
\text { per thousand } \\
\text { population }\end{array}$ \\
\hline 1991 & 838 & 4.85 & 5.77 \\
\hline 1997 & 970 & 6.67 & 6.87 \\
\hline 2000 & 1000 & 8.61 & 8.61 \\
\hline 2005 & 1100 & 12.00 & 10.90 \\
\hline 2010 & 1180 & 61.8 & 14.24 \\
\hline 2015 & 1250 & 21.54 & 17.23 \\
\hline 2020 & 1320 & 28.5 & 21.62 \\
\hline 2025 & 1380 & 37.21 & 26.96 \\
\hline
\end{tabular}

Stock of Scientific \& Technical Persons per Thousand Population for selected Countries in the World (1990)

\begin{tabular}{|c|l|r|r|l|r|c|l|r|}
\hline S. No. & Country & Stock & S. No. & Country & Stock & S. No. & Country & Stock \\
\hline 1. & Canada & 18.6 & 10. & Israel & 82.5 & 19. & USA & 21.1 \\
\hline 2. & USSR & 139.2 & 11. & Australia & 53.6 & 20. & Cuba & 14.4 \\
\hline 3. & Sweden & 113.6 & 12. & Korea & 53.1 & 21. & Brazil & 11.2 \\
\hline 4. & Japan & 112.8 & 13. & Hungary & 50.00 & 22. & China & 8.4 \\
\hline 5. & Venezuela & 107.8 & 14. & Spain & 45 & 23. & Pakistan & 4.1 \\
\hline 6. & Denmark & 97.8 & 15. & Philippines & 36.6 & 24. & India & 3.8 \\
\hline 7. & UK & 89.5 & 16. & Argentina & 34.8 & 25. & Indonesia & 3.5 \\
\hline 8. & Germany & 85.1 & 17. & Singapore & 26.6 & 26. & Nigeria & 1.4 \\
\hline 9. & Italy & 83.1 & 18. & Austria & 21.6 & 27. & Guyana & 1.3 \\
\hline
\end{tabular}




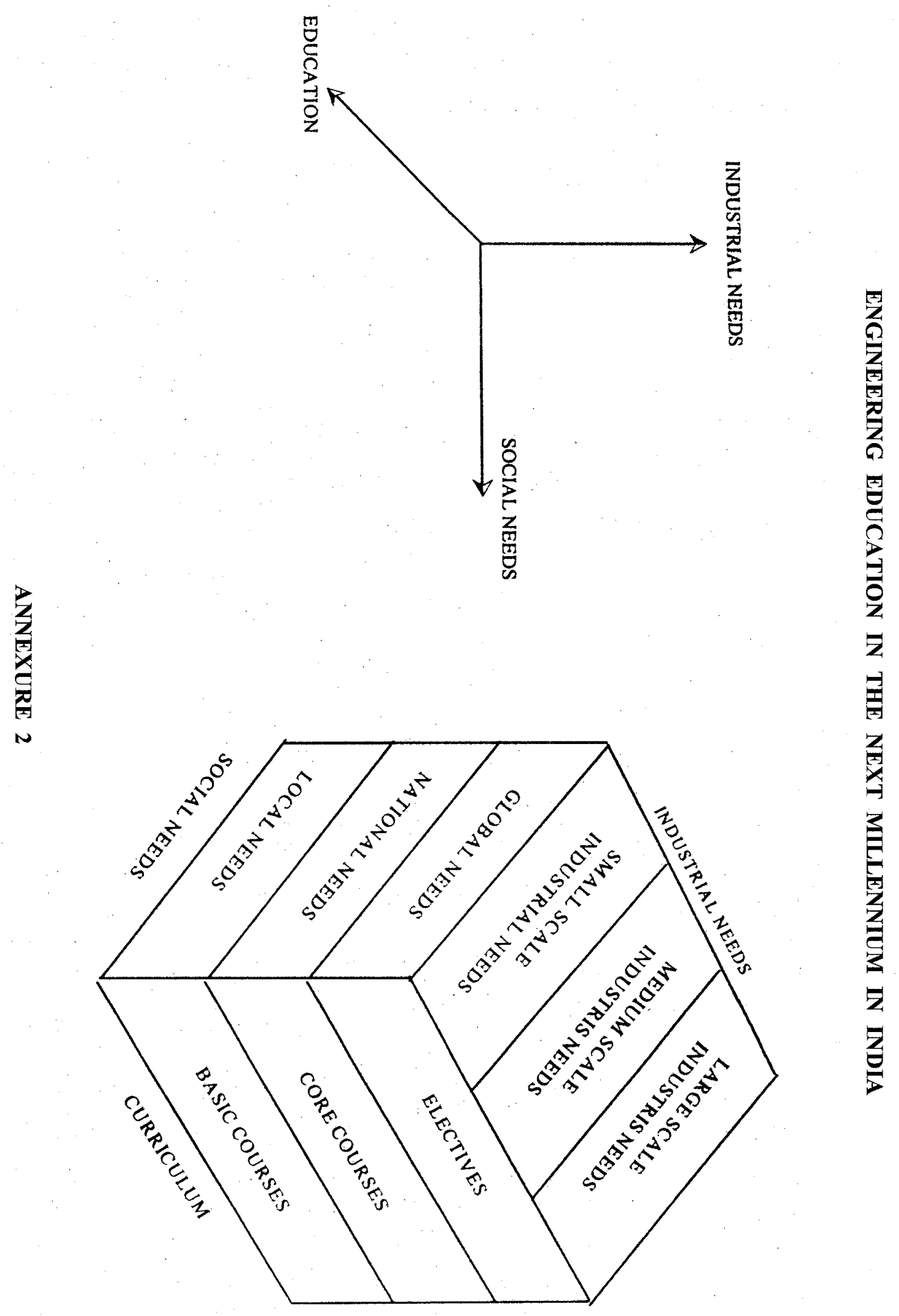

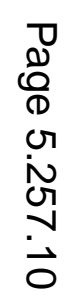


ENGINEERING EDUCATION IN THE NEXT MILLENNIUM IN INDIA

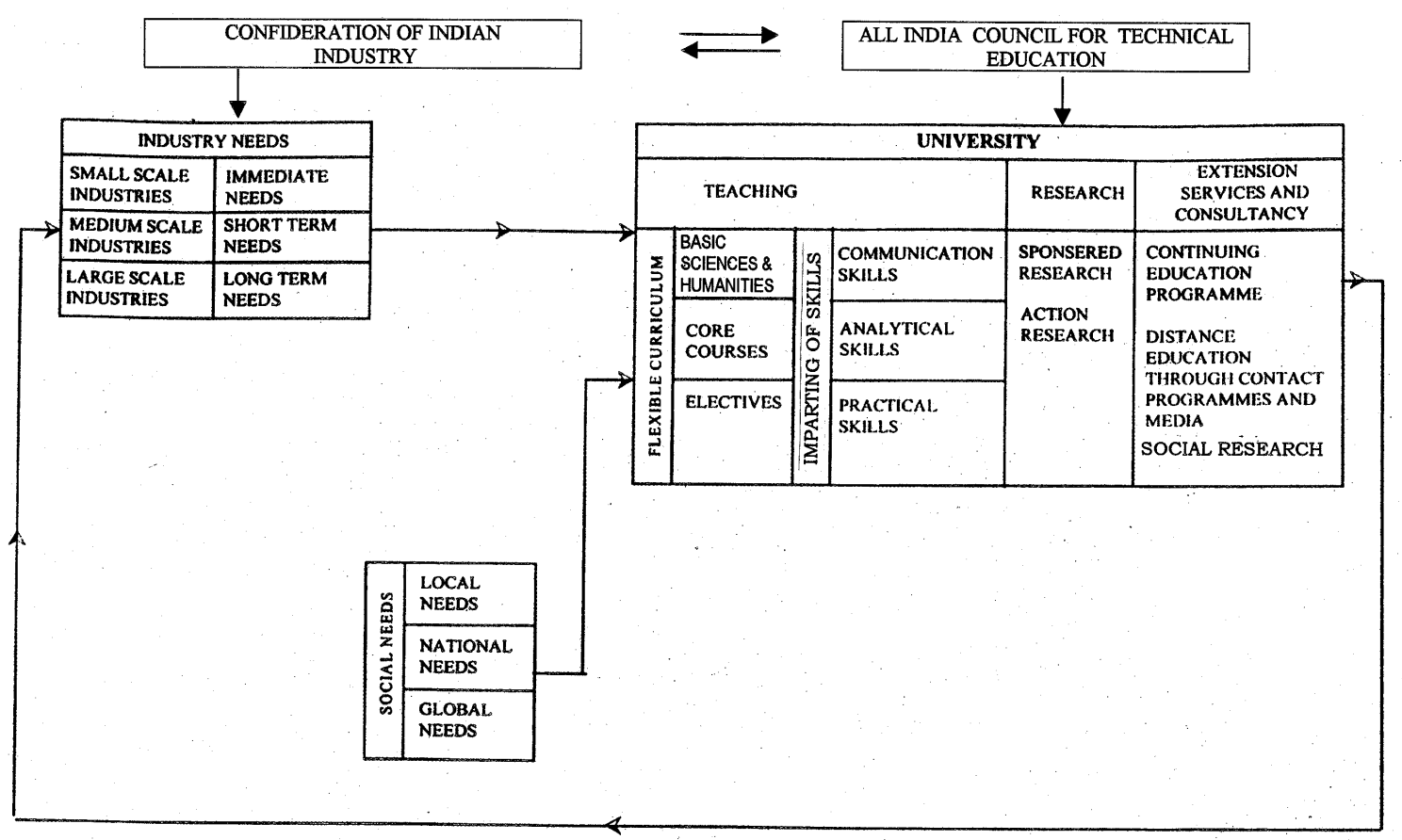

ANNEXURE 3 
ENGINEERING EDUCATION IN THE NEXT MILLENNIUM IN INDIA

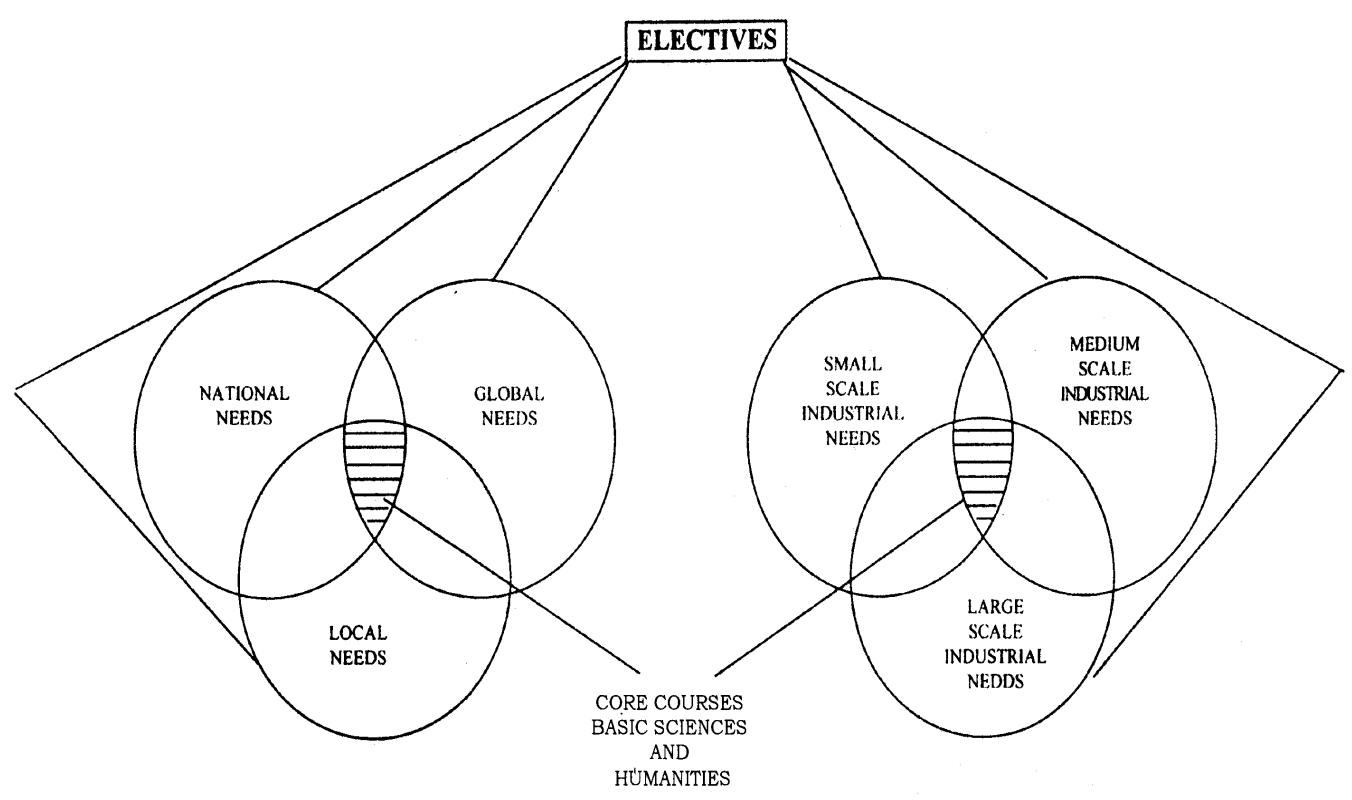

ANNEXURE 4

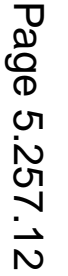

